\title{
CONTAGIOUS AGALACTIA BY MYCOPLASMA AGALACTIAE IN SMALL RUMINANTS IN BRAZIL: FIRST REPORT
}

\author{
Edisio Oliveira de Azevedo ${ }^{1 *}$; Maria Dalva Bezerra de Alcântara²; Elmiro Rosendo do Nascimento ${ }^{3}$; \\ Ivon Macedo Tabosa ${ }^{1}$; Maria Lúcia Barreto ${ }^{3}$; Juliana Ferreira de Almeida ${ }^{3}$; Marília D’Oliveira Araújo ${ }^{1}$; \\ Ana Rosa Oliveira Rodrigues ${ }^{1}$; Franklin Riet-Correa ${ }^{1}$; Roberto Soares de Castro ${ }^{4}$
}

${ }^{1}$ Universidade Federal de Campina Grande/Campus de Patos - PB; ${ }^{2}$ Empresa Estadual de Pesquisa do Estado da Paraíba - PB; ${ }^{3}$ Universidade Federal Fluminense - Niterói - RJ; ${ }^{4}$ Universidade Federal Rural de Pernambuco/Campus de Recife - PE

Submitted: January 03, 2006; Returned to authors for corrections: March 13, 2006; Approved: October 13, 2006

\begin{abstract}
Two outbreaks of contagious agalactia by Mycoplasma agalactiae occurred in Paraíba State, Northeastern Region of Brazil are reported. The disease was characterized by mastitis, agalactia and polyarthritis in does and polyarthritis and conjunctivitis in kids and lambs. Fever and anorexia were also observed. Morbidy was from $26.1 \%$ to $100 \%$ in does, 36.5 to $100 \%$ in kids and $49 \%$ in lambs. In one farm $14.3 \%$ of the lactating goats and $6.4 \%$ of the kids died or were euthanized. In the other, $3.3 \%$ of the does, $36.5 \%$ of the kids and $22.9 \%$ of the lambs died and 84 affected goats were euthanized to control the disease. M. agalactiae was isolated from milk, joint exudates, nasal swabs and ear washings. The colonies were characteristic of Mycoplasma and the agent did not ferment both glucose and arginin. It was typed as Mycoplasma agalactiae by immunoperoxidase and PCR. This is the first report of M. agalactiae infection in Brazil, but the source of the infection remains unknown.
\end{abstract}

Key words: contagious agalactia, Mycoplasma agalactiae, small ruminants

\section{INTRODUCTION}

Mycoplasma agalctiae causing contagious agalactia (ACOC) was the first Mycoplasma isolated from sheep and goats (19). Other important Mycoplasma affecting goats are $M$. capricolum subsp capricolum which causes contagious caprine pleuropneumonia (CCPP), M. conjunctivae, M. arginini, $M$. mycoides subsp mycoides and $M$. mycoides subsp capri $(14,20,28)$.

ACOC occurs in Europe, Asia and Africa, mainly in the countries around the Mediterranean $(11,12,25,28)$ causing important losses due to decreased milk production, death of animals and cost of treatment and prevention. The disease is characterized by mastitis, agalactia, polyarthritis, keratoconjunctivitis and occasionally, abortion and pneumonia. The main agent of ACOC is Mycoplasma agalactiae, although
M. capricolum subsp capricolum, M. mycoides subsp mycoides (large colony), M. putrfaciens and M. mycoides subsp capri can also cause the disease $(13,19)$. Goats infected by $M$. mycoides subsp capri and $M$ mycoides subsp. mycoides LC can have mastitis and pneumonia and arthritis $(17,28)$.

The incubation period of infection by M. agalactiae in goats and sheep is one to eight weeks. Initially, affected animals are depressive, anorectics and pyrexia, followed by sudden drop of milk production, mastitis, agalactia, and polyarthritis mainly in the carpal and tarsal joints. Pneumonia and abortion can also occur in chronically infected animals (29). M. agalactiae and other mycoplasmas can be isolated from the external auditory duct and from Raillietia caprae or Psoroptes cuniculi that parasites wich can be found in the the outer ear of sheep and goats and have been involved in the maintenance of the infection in carrier animals (6).

*Corresponding Author. Mailing address: Unidade Acadêmica de Medicina Veterinária - Centro de Saúde e Tecnologia Rural - Universidade Federal de Campina Grande - Campus de Patos, PB - Av. Universitária s/n Santa Cecília cep 58708-110 Patos, PB - Brasil. Tel.: (83) 3421-3397 r.222 ou (83) 3421-4659. E-mail: edisio@cstr.ufcg.edu.br 
In Brazil ACOC was reported by the first time in 1942 in the state of São Paulo, however the isolated Mycoplasma was not identified (22). Pneumonia, keratoconjunctivitis and arthritis caused by organisms related to M. mycoides subsp mycoides and M. mycoides subsp capri have been reported (21). Mycoplasma spp and $M$. arginini have been isolated from goats with polyarthritis and pneumonia, respectively $(4,14)$. M. mycoides subsp mycoides SC (small colony) have been recovered from the external auditory meatus of clinically normal goats (23). $M$. conjuntivae have been identified from sheep and goats with and without clinical signs of keratoconjunctivitis $(1,15)$.

The aim of this paper is to report contagious agalactia by Mycoplasma agalactia in goats and sheep for the first time in Brazil.

\section{MATERIALAND METHODS}

\section{Animals, clinical signs and pathology}

The two outbreaks occurred in the state of Paraíba, Northeastern of Brazil. The first one occurred from August to November 2001, and the second from December 2001 to January 2002. From 265 animals of the first affected herd (British Alpine, Anglo Nubian and Brown Alpine), 109 were lactating kids and 156 adult does, including 89 lactating does with a daily mean milk production of $2.1 \mathrm{~kg}$. In this farm the kids were separated from does immediately after parturition. The second affected herd had 172 adult does and 8 adult males that included Saanen, Toggenburg and Anglo Nubian, recently acquired in different commercial dairy goats herds from the states of São Paulo, Minas Gerais and Pernambuco to start milk production. This farm had also animals for meat production, including 52 Boer goats and 200 Santa Inês and Dorper sheeps kept in an intensive production system and 1500 sheep in a semi-intensive system.

Affected animals were clinically examined, mainly in relation to respiratory and locomotor systems, udder and eyes. Four kids and four goats severely affected were euthanized and necropsied. Samples of joint capsule, udder, lung, heart, spleen, lymphnodes, kidney and central nervous system were fixed in $10 \%$ buffered formalin, embedded in paraffin, cut at six $\mu \mathrm{m}$, and stained by hematoxylin-eosin.

\section{Isolation and identification of Mycoplasma}

The clinical specimens used in this study are listed in Table 1. The nasal swabs were placed in tubes with the cotton part immersed in approximately $2 \mathrm{ml}$ of a solution with $50 \%$ glycerol in PBS (PBS-G). Joint exudates, milk, and washings with mites from the external ear were homogenized (v/v) with PBS-G. Then in PBS-G the specimens were shipped in ice boxes to the laboratory and stored in freezer at $-20^{\circ} \mathrm{C}$.

The samples $(200 \mu \mathrm{l})$ were inoculated in solid Hayflick modified medium (31), incubated at $37^{\circ} \mathrm{C}$ and observed daily a stereoscopic microscope at 40x to 100x to source colonies with
Table 1. Clinical specimens used for Mycoplasma isolation.

\begin{tabular}{lccccc}
\hline Specie & Milk & $\begin{array}{c}\text { Joint } \\
\text { exudate }\end{array}$ & $\begin{array}{c}\text { Nasal } \\
\text { swabs }\end{array}$ & $\begin{array}{c}\text { External ear } \\
\text { washings }\end{array}$ & Total \\
\hline Caprine & 11 & 08 & 06 & 29 & 54 \\
Ovine & - & - & 16 & 37 & 53 \\
\hline
\end{tabular}

a fried egg aspect. Fragments of agar with the colonies were transferred to tubes containing $3 \mathrm{ml}$ liquid Hayflick medium, which were incubated at $37^{\circ} \mathrm{C}$ for $72-96 \mathrm{~h}$. Then, $300 \mu \mathrm{l}$ of the diluted $\left(10^{-1}\right.$ to $\left.10^{-6}\right)$ culture were re-inoculated in plates with solid medium to isolate colonies, observe films and spots production and perform Dienes stain (10).

\section{Indirect immunoperoxidase test}

Areas of typical colonies were used for typification by the indirect immunoperoxidase test reported by Imada et al. (16) with some modifications. The incubation period was prolonged from one to four hours during the phase of antiserum adsorption and from one to three hours in the phase of reaction with the conjugate. Immediately before using the serum was diluted (1:20) in TBS (50 mM Trizma and $100 \mathrm{mM} \mathrm{NaCl}$ at $\mathrm{pH} 7.4$ ), and the conjugate diluted (1:50) in TBBS (TBS with $1 \%$ of bovine serum albumine). Initially, paper discs saturated with $25 \mu \mathrm{l}$ of hyperimmune rabbit serums against $M$. agalactiae, $M$. capricolum, M. putrefaciens, and M. arginini were placed over the colonies in solid media and incubated at $37^{\circ} \mathrm{C}$ for four hours. Then, the discs were replaced by new discs previously embedded in $25 \mu \mathrm{l}$ of anti-rabbit conjugate labeled with peroxidase and incubated for three hours at $37^{\circ} \mathrm{C}$. After incubation, each plate was washed in $10 \mathrm{ml}$ washing buffer ( $100 \mathrm{ml} \mathrm{TBS}$ plus $2.0 \mathrm{ml}$ equine serum plus $50 \mu$ tween 20 ) and immediately revealed by the addition of a solution ( $10 \mathrm{ml}$ of methanol plus $30 \mathrm{mg}$ 4-cloro1-naphtol plus $50 \mu \mathrm{l}$ TBS plus $30 \mu \mathrm{H}_{2} \mathrm{O}_{2}$ ). This revelation was performed at room temperature and protected from light for 30 min. It was observed a stereoscopic microscope and considered positives the colonies with brown discoloration.

\section{Polymerase Chain Reaction}

DNA samples for PCR were prepared by phenol-chloroform method. Briefly, one ml culture were centrifuged at 20,000 $\times g$ for $20 \mathrm{~min}$ at $4^{\circ} \mathrm{C}$. The pellets were then re-suspended in $400 \mu \mathrm{l}$ of lysis buffer [Dextrose-EDTA buffer, pH 8.4, plus $30 \mu \mathrm{l}$ of proteinase K $(240 \mu \mathrm{g} / \mathrm{ml})$ plus $30 \mu \mathrm{l}$ of SDS-Sodium Dodecyl Sulphate, $10 \%$ ], and incubaded for $30 \mathrm{~min}$ at $50^{\circ} \mathrm{C}$. After fast cooling it was carried out double extraction with $500 \mu$ l of phenol (pH 7.8) followed by one extraction with $500 \mu \mathrm{l}$ of chloroform and addition of $100 \mu \mathrm{l}$ of ethanol to the final aqueous phase and stored overnight at $-20^{\circ} \mathrm{C}$. Samples were centrifuged at $20,000 \times g$ for $10 \mathrm{~min}$ at $4^{\circ} \mathrm{C}$ and the pellets were re-suspended 
in $100 \mu \mathrm{l} \mathrm{TE}$ buffer (10 mM Tris-HCl, 1 mM EDTA, pH 8.0). For M. agalactiae-specific amplification the primers set 5'-CCT TTT AGATTG GGATAG CGGATG - 3' and 5'-CCGTCAAGG TAG CGT CAT TTC CTA C - 3' derived from the Mycoplasma agalactiae PG2 strain were used (GenBank access number U44763) as published by Chávez González et al. (5). The PCR reaction was conducted using thermocycler (mod. PTC-100, MJ Research). The reaction volume was $100 \mu \mathrm{l}$, with $59 \mu \mathrm{l}$ of MilliQ water, $10 \mu \mathrm{l}$ PCR buffer (10x), $5 \mu \mathrm{MgCl}_{2}, 5 \mu \mathrm{l}$ of each dNTP mix $(0.25 \mathrm{mM}), 2 \mu \mathrm{l}$ of each primer, $15 \mu \mathrm{l}$ DNA extracts, $2 \mathrm{U}$ Taq Polymerase and $50 \mu \mathrm{l}$ of mineral oil to overlay the mixture. The PCR was performed by using one cycle at $95^{\circ} \mathrm{C}$ for $5 \mathrm{~min}$, the denature step followed by 40 cycles of denaturation at $94^{\circ} \mathrm{C}$ for $1 \mathrm{~min}$, annealing at $57^{\circ} \mathrm{C}$ for $1 \mathrm{~min}$, extension at $68^{\circ} \mathrm{C}$ for $1 \mathrm{~min}$, and finally an extra extension at $70^{\circ} \mathrm{C}$ for $10 \mathrm{~min}$. Bands were run and analyzed on $2 \%$ agarose stained with ethidium bromide $(0.5 \mathrm{pg} / \mathrm{ml})$ and visualized under ultraviolet light after electrophoresis.

\section{RESULTS}

\section{Epidemiology, clinical signs and pathology}

In the first affected herd clinical signs included observed mastitis and agalactia in four goats, characterized by flaccid udder with aqueous secretion with presence of clots. Five days later, 21 other goats had mastitis with arthritis and fever. At the same time, 21 kids had fever lameness with enlarged and painful joints, mainly in the forelegs, and difficult gait with rigidity and dorsal flexion. After two weeks, all the 89 milking goats presented mastitis and agalactia. There was a fall of $90 \%$ of milk yield and milking was suspended. In a period of 120 days, 43 out of 89 goats $(48.3 \%)$ had also arthritis or polyarthritis. Affected goats were treated with $20 \mathrm{mg} / \mathrm{kg}$ tylosin daily, during five days. Most animals recovered, although seven were euthanized and seven died spontaneously. At the same time all kids were affected and some of them were treated in the same way. Four of the 109 kids (3.7\%) died and three $(2.7 \%)$ were euthanized. No cases were observed in the group of non lactating does, which was separated from the affected goats at the start of the outbreak.

In the other herd, three weeks after the first parturition, two lactating goats had anorexia, mastitis, agalactia and arthritis, and six kids and eight lambs had arthritis, conjunctivitis, fever and anorexia. In 15 days 40/63 (63.5\%) kids, 30/61 (49\%) lambs, and 18/180 (10\%) goats were affected. Twenty three (36.5\%) kids, $14(22.9 \%)$ lambs, and six (3.3\%) goats died. In the same period 84 adult non lactating goats were separated from the flock as a control measure. These animals were not affected. Thirty days after the initiation of the outbreak 88 adult goats and eight bucks from the dairy goat herd were euthanized for control measure. Thirty seven of these had arthritis, mastitis and/or conjunctivitis, and 51 had no clinical signs. No clinical cases were observed in adult Boer goat. Among adult sheep, only two had arthritis and anorexia, but recovered after treatment with tylosin as described above.

At necropsies tumefaction of the joint capsule with presence within the joint of yellow viscous exudates with fibrin were observed in the animals with arthritis. On the histologic examination the joint capsule had infiltration of neutrophils, areas of necrosis, edema, and occasionally microabscesses. In one kid the spleen had diffuse necrosis of the white pulp, but the germinative centers were not affected. Another kid had an area of consolidation in the right apical lobe. Histologically, this lesion was characterized by interstitial pneumonia with mononuclear infiltration. The mammary gland contained yellow exudates with clots. Histologically, the gland had severe infiltration of mononuclear cells and neutrophils in the connective tissue, atrophy of the secretor ducts, and occasionally desquamation of the epithelial cells. Eosinophilic contents and cellular debris were observed within the ducts (Fig. 1).

\section{Isolation and identification of Mycoplasma agalactiae}

Mycoplasma positive to the Dienes test were isolated from joint exudates of two does, one kid and one lamb with polyarthritis, milk samples of four does with mastitis, nasal swabs from four kids without respiratory signs, and the ear washings of one pregnant does, one buck with arthritis, and two apparently healthy adult sheep. All isolates showed transparent colonies with fried egg appearance, and yelded films and spots on solid

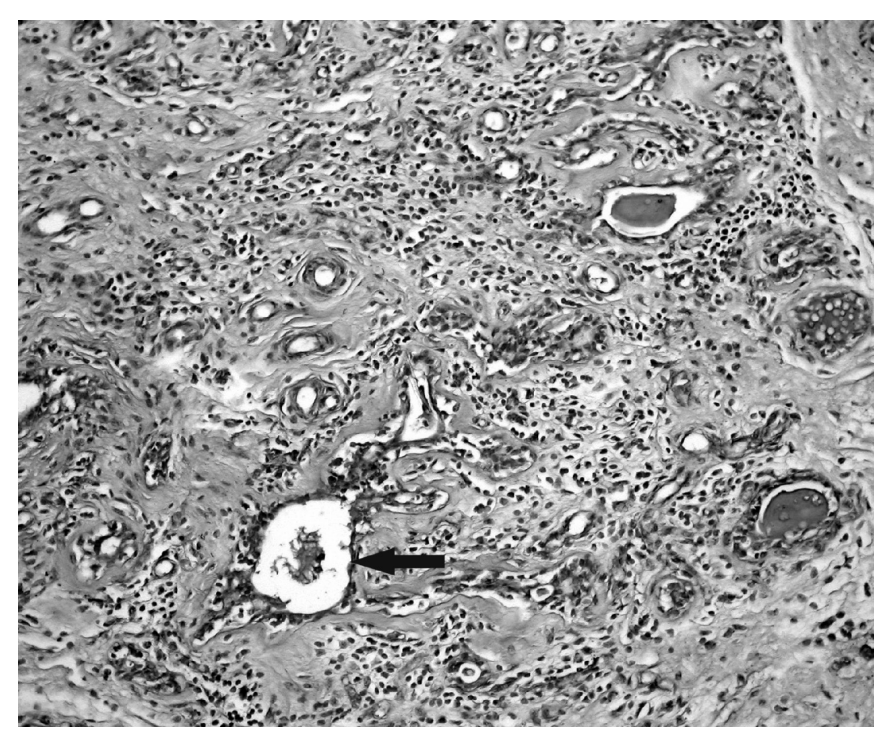

Figure 1. Udder. Goat infected by M. agalactiae. There is severe infiltration by mononuclear cells and neutrophils in the interstitial tissue. Eosinophilic exudates is observed within the ducts, and in some ducts the epithelium is desquamated (arrow). HE, $x 100$. 
Hayflick medium supplemented with equine serum. The bacteria did not fermented glucose and arginin.

Agar blocks with typic Mycoplasma colonies from all culture species, when submitted to immunoperoxidase test, exhibited positive reactions only to $M$. agalactiae.

On the PCR test, all isolates showed specific amplicon at 360 bp to M. agalactiae (Fig. 2).

Psoroptes cuniculi was observed on ear washings of $68 \%$ (20/29) goats, and $37.8 \%$ (14/37) sheep.

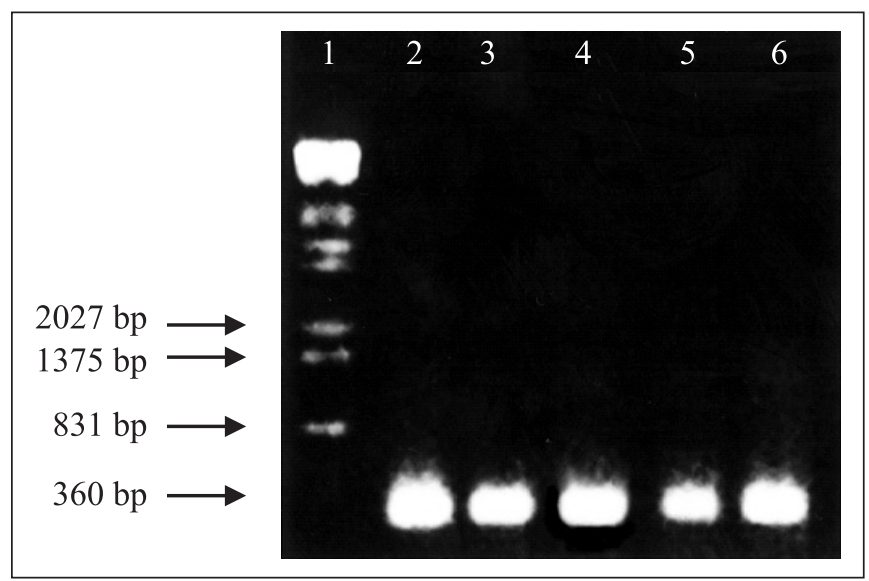

Figure 2. PCR: line 1, PM (DNA- $\lambda$, EcoRI + HindIII); line 2, $M$. agalactiae GM139; line 3-6, isolates from the milk (3), nasal swab (4), joint exudates (5) and external ear washing (6).

\section{DISCUSSION}

The results reported in this paper confirmed for the first time in Brazil the occurrence of Mycoplasma agalactiae as an agent of ACOC. Agalactia and lameness were reported in São Paulo in a goat that died without significant lesions some months after been affected. Some kids from the same herd died with pulmonary congestion and at necropsy one of them had hyperemic foci in the lung. Microorganism with characteristics of Mycoplasma was isolated from the goat, and the bacterium was inoculated in kids causing lameness, enlargement of the prescapular lymph nodes, and death in five days. At necropsy, hyperemic foci were observed on the lung and gut (23). ACOC caused by $M$. agalactiae occurs in countries with intensive rearing of sheep and goats $(3,7,11,12,18,25,30)$.

In these outbreaks the identification of the isolates was performed by their culture characteristics as well as by the immunoperoxidase test and PCR. PCR is faster than the traditional tests and it can be used as confirmatory test in the diagnosis of ACOC, even after storage of the samples at $-20^{\circ} \mathrm{C}$ for 24 months (30). The high morbidity of the disease (26.1\% to
$100 \%$ of the goats, 36.5 to $100 \%$ of kids, and $49 \%$ of lambs), suggests that the disease was introduced in farms where the $M$. agalactiae did not exist previously. After the occurrence of these outbreaks, the disease spread to Paraíba, Rio Grande do Norte, and Pernambuco States causing important economical losses. However, after the introduction of the agent in the farms the disease became enzootic with sporadic cases (unpublished data). These features strongly suggest that $M$. agalactiae was introduced in the Northeastern region and probably in Brazil, where the disease had not been reported. The source of the infection remains unknown, but until 1988 the farm where the first outbreak occurred imported goats and sheep from other countries, and the other farm bought many animals from the states of São Paulo, Minas Gerais and Pernambuco to start dairy production.

The infection was probably introduced by carrier animals, which are very important in epidemiology of the disease. In this study the role of carrier animals is suggested by the isolation of $M$. agalactiae after five days of treatment with tylosin, and also from the ear washings of sheep and goats infected by Psoroptes cuniculi. In other countries P. cuniculi is highly prevalent in goats and $M$. agalactiae has been isolated from this acarid $(6,8)$. Other acarid, Railletia caprae that also can be a carrier of Mycoplasm spp is the most prevalent in other Brazilian regions (26).

The main clinical signs observed in the outbreaks reported in this paper were mastitis and agalactia in the does, and polyarthritis in kids and lambs, but numerous does had also polyarthritis. The high frequency of mastitis and agtalactia in goats with some of them having arthritis is highly suggestive of infection by $M$. agalactiae. Other causes of mastitis are commonly observed in goats in Northeastern Brazil, but without the high frequency of agalactia and arthritis observed in these outbreaks. To EGWO et al. (11) the observation of agalactia is suggestive of $M$ agalactiae infection. In non milking goats other common causes of arthritis can be confused with infection by $M$ agalactiae, including other Mycoplasma and bacterial infections, virus infections and traumatic injuries, which are common in young animals, but the high frequency of polyarthritis is suggestive of Mycoplasma infection. In cases of arthritis by M. agalactiae, the thickening of the joint capsule, the liquid aspect of the exudates, the absence of umbilical lesions or abscesses in other organs, associated with the high prevalence of polyarthritis suggest the infection by $M$. agalactiae $(2,9)$, but other Mycoplasma, including M. mycoides subsp. capri can also cause high frequency of arthritis $(21,25)$. Despite the observation of a small lesion of interstitial pneumonia in one kid, respiratory signs were not observed in these outbreaks. Respiratory signs are frequently observed in goats infected by M. mycoides subsp mycoides, M. capricolum subsp capricolum, and M. mycoides subsp capri (27). M. agalactiae have been also isolated from goats with lung lesions $(3,25)$ 
The occurrence of ACOC by M. agalactiae in Brazil suggests that the diagnosis of Mycoplasma infections of the sheep and goats should be introduced in the routine diagnostic laboratories. In the country, other Mycoplasma, including $M$. mycoides subsp mycoides, M. mycoides subsp capri, $M$. arginini, and Mycoplasma spp, have been isolated in goats and sheep with pneumonia, mastitis, arthritis or keratoconjunctivitis $(1,4,14,15,21,23,24,26)$, but their economic importance remains unknown.

\section{RESUMO}

\section{Agalaxia contagiosa por Mycoplasma agalactiae em pequenos ruminantes no Brasil: Primeiro relato}

Dois surtos de agalaxia contagiosa causada por Mycoplasma agalactiae são descritos no Estado da Paraíba, região Nordeste do Brasil. A doença caracterizou-se por mastite, agalaxia e poliartrite em cabras e poliartrite e cerato-conjuntivite em cabritos e cordeiros. Febre e anorexia também foram observadas. A morbidade variou de $26,1 \%$ a $100 \%$ nas cabras, $36,5 \%$ a $100 \%$ em cabritos e $49,0 \%$ em cordeiros. Na primeira fazenda, $14,3 \%$ das cabras em lactação e 6,4\% dos cabritos morreram ou foram sacrificados. Na outra propriedade, $3,3 \%$ dos caprinos adultos, $36,5 \%$ dos cabritos e $22,9 \%$ dos cordeiros morreram e outros 84 caprinos foram sacrificados para controle da doença. $M$. agalactiae foi isolado a partir de leite, líquido articular, suabe nasal e lavado do conduto auditivo externo. Colônias características de Mycoplasma e que não fermentaram a glicose e arginina foram observadas. A identificação de M. agalactiae foi realizada por imunoperoxidase indireta e PCR. Sendo assim, M. agalactiae é descrito pela primeira no Brasil, mas a origem da infecção permanece desconhecida.

Palavras-chave: agalaxia contagiosa; Mycoplasma agalactiae, pequenos ruminantes

\section{REFERENCIAS}

1. Almeida Neto, J.B.; Sá, F.B.; Buzinhani, M.; Timenetsky, J.; Mota, R.A.; Almeida, M.Z. (2004). Ocorrência de Mycoplasma conjuntivae em ovinos sadios e com ceratoconjuntivite infecciosa, no Estado de Pernambuco. Arq. Inst. Biol., 71(1), 79-81.

2. Bajmocy, E.; Turcsanyi, I.; Bolske, G.; Bacsadi, A.; Kiss, I. (2000). Disease caused by Mycoplasma mycoides subspecies mycoides LC in Hungarian goat herds. Acta Vet. Hung., 48(3), 277-283.

3. Banerjee, M.; Singhi, N.; Gupta, P.P. (1979). Isolation of Mycoplasmas and Acholeplasmas from pneumonie lesions in sheep and goats in India. Zbl. Vet. Med. B., 26, 689-695.

4. Castro, R.S.; Pessoa, A.L.P.; Maia, F.C.L.; Tabosa, H.C.; Cavalcante, M.I.; Barros, M.S.R.M. (1989). Micoplasmoses em reprodutores empregados em programa de melhoramento genético no Estado de Pernambuco, Brasil. Arq. Bras. Vet. Zootec., 41, 247-256.

5. Chávez-González, Y.; Bascunana, C.R.; Bolske, J.G.; Mattson, J.B.; Molina, C.F.; Johansson, K.-E. (1995). In vitro amplification of the
16S rRNA genes from Mycoplasma bovis and Mycoplasma agalactiae by PCR. Vet. Microbiol., 47, 183-190.

6. Cottew, G.S.; Yeats, F.R. (1982) Mycoplasmas and mites in the ears of clinically normal goats. Aust. Vet. J., 59, 77-81.

7. DaMassa, A.J. (1983a). Recovery of Mycoplasma agalactiae from mastitic goat milk. J. Am. Vet. Med. Assoc., 183(5), 548-549.

8. DaMassa, A.J. (1983b). Prevalence of Mycoplasmas and mites in the external auditory meatus of goats. Calif. Vet., 37(10), 13-17.

9. Damassa, A.J.; Brooks, D.L.; Holmberg, C.A. (1986). Induction of mycoplasmosis in goats kids by oral inoculation with Mycoplasma mycoides subspecies mycoides. Am. J. Vet. Res., 47(9), 2084-2090.

10. Dienes, L. (1945). Morphology and nature of the pleuropneumonia group of organisms. J. Bacteriol., 50, 441-458.

11. Egwu, G.O.; Ameh, J.A.; Aliyu, M.M.; Mohammed, F.D. (2001). Caprine mycoplasmal mastitis in Nigeria. Small Rum. Res., 39, 87-91.

12. Fasanya, O.O.A.; Adegboye, D.S.; Molokwu, E.C.I.; Dim, N.I. (1987). Microbiology of the genitlia of nulliparous and postpartum savanna brown goats. Vet. Res. Com., 11, 191-198.

13. Gil, M.C.; Pena, F.J.; Hermoso De Mendonza, J.; Gomez, L. (2003). Genital lesions in an outbreak of caprine contagious agalactia caused by Mycoplasma agalactiae and Mycoplasma putrefaciens. J. Vet. Med. B Infect. Dis Vet Public Health., 50(10), 484-487.

14. Gomes, M.J.P.; Feitosa, M.H.; Khral, M.; Fernandes, R.E.; Nascimento, E.R.; Portugal, M.A.S.L. (1994). Micoplasmose caprina: pneumonia. Primeiro relato no Brasil de Mycoplasma arginini. Hig. Alim., 8, 18-20.

15. Gregory, L.; Cardoso, M.V.; Birgel Jr., E.H.; Teixeira, S.R.; Souza, R.M.; Pacheco, W.A.; Birgel, E.H.; Benesi, F.J. (2003). Surto de ceratoconjuntivite infecciosa dos caprinos causada por Mycoplasma conjunctivae em caprinos adultos, criados no Estado de São Paulo. Arq. Inst. Biol. São Paulo, 70(2), 199-201.

16. Imada, Y.; Uchida, I.; Hashimoto, K. (1987). Rapid identification of Mycoplasma by indirect immunoperoxidase test using small square filter paper. J. Clin. Microbiol., 25, 17-21.

17. Kumar, H.; Parihar, N.S.; Charan, K.; Singh, K.P. (1994). Pathology and bronchoscopic studies in Mycoplasma mycoides subsp. capri in goats. Indian J. Anim. Sci., 64, 999-1005.

18. Madanat A.; Zendulková, D.; Pospíśil, Z. (2001). Contagious agalactia of sheep and goats. A review. Acta Vet. Brno., 70, 403-412.

19. Madanat A.D.; Zendulková, P.; Lány, Z.; Pospíšil, P. Ėíhal. (2002). Prevalence of Mycoplasma agalactiae Antibodies in Czech and Jordanian Herds of Small Ruminants. Acta Vet. Brno., 71, 37-44.

20. March, J.B.; Gammack, C.; Nicholas, R. (2000). Rapid detection of contagious caprine pleuropneumonia using a Mycoplasma capricolum subsp. capripneumoniae capsular polysaccharide-specific antigen detection latex agglutination test. J. Clin. Microbiol., 38(11), 41524159.

21. Nascimento, E.R.; Nascimento, M.G.F.; Freund, E.A.; Andersen, H. (1986). Isolation of Mycoplasma mycoides from outbreaks of caprine mycoplasmosis in Brazil. Br. Vet. J., 142, 246-257.

22. Penha, A.M.; D' Apice, M. (1942). Agalaxia contagiosa das cabras em São Paulo. Arq. Inst. Biol., 13: 299-301.

23. Pereira, L.O.; Danelli, M.G.M.; Mazur, C.; Galler, R. (2003). Identificação molecular de Mycoplasma mycoides subesp. mycoides SC isolado do conduto auditivo externo de caprinos clinicamente saudáveis. Ciênc. Rur., 33(2), 367-368.

24. Perreau, P.; Cuong, T.; Vallée, A. (1972). Isolement d'un mycoplasma du groupe Mycoplasma mycoides var. capri à partir d'un lait de mammite chez la chévre. Bull. Acad. Vet. Fr., 45, 109-116.

25. Real, F.; Déniz, S.; Acosta, B.; Ferrer, O.; Poveda, J.B. Caprine contagious agalactia caused by Mycoplasma agalactiae in the Canary Islands. Vet. Rec., 135, 15-16, 1994.

26. Ribeiro, V.R.; Nascimento, E.R.; Faccini, J.LH.; Nascimento, M.G.F.; Lignon, G.B. (1995). Presença de micoplasma em exemplares de 
Raillietia caprae coletados do conduto auditivo externo de caprinos. Rev. Bras. Med. Vet., 17, 122-124.

27. Rodriguez, J.L.; Fernandez, A.; Oros, J.; Ramirez, S.A.; Luque, R.; Ball, H.J.; Sarradel, J. (2001). Change in lymphocyte subsets in the bronchus-associated lymphoid tissue of goats naturally infected with different Mycoplasma species. J. Vet. Med., B. 48, 259-266.

28. Singh, V.P.; Srivastava, N.C.; Kumar, M.; Sunder, M.J.; Varshney, J.P (2004). Isolation and characterisation of an Indian strain of Mycoplasma mycoides subsp. mycoides type LC from a case of caprine arthritis. Comp. Immunol. Microbiol. Infect. Dis., 4(27), 273-284.
29. Smith, M.C.; Sherman, D.M. (1994). Goat Medicine. Philadelphia USA: Lea \& Febiger, 620p.

30. Tola S.; Angioi, A.; Rocchigiani A.M.; Idini, G.; Manunta, D.; Galleri, G.; Leori G. (1997). Detection of Mycoplasma agalactiae in sheep milk samples by polymerase chain reaction. Vet. Microbiol., 54, 17-22.

31. Whitford, H.W.; Rosenbusch, R.F.; Lauerman, L.H. (1994). Mycoplasmosis in Animals: Laboratory Diagnosis. Ames: lowa S. Univ. Press. 173p. 